\title{
CORRESPONDENCE
}

\section{Science and Politics}

SIR,-Your most recent contributors to the debate on NATO sponsorship display remarkable skill in casuistry. I have just returned from a NATO sponsored International Summer School at the University of Antwerp on Modular Functions of One Variable and Arithmetical Applications; and for me it proved impossible to isolate intellectual interest in the pure mathematics from feelings of disquiet that one was participating in an Institute which could be held to legitimize NATO, or at least to lend its name spurious respectability. After the opening speeches of the conference, the participants were addressed unofficially by A. Grothendieck, one of France's most distinguished mathematicians and a well-known opponent of military involvement in mathematical research. $\mathrm{He}$ exhorted us to consider the implications of our attendance, and throughout the lavish reception following, sat among us sending up balloons bearing anti-NATO slogans. This disturbed and angered many of the visitors. Discussion was renewed in the second week with the circulation of a long statement of protest by R. Godement of France, while in the interim a number of participants endeavoured unsuccessfully to arrange a meeting with a NATO spokesman to discuss the aims of their Scientific Affairs Division. Finally, I decided that the only way to atone for my own involvement was to repay the US\$100 grant from the sponsors and never to attend such a conference again.

It seems to me that the Summer School was spoiled from the beginning by its sponsorship. The organizers of such a conference are fully aware that a proportion of the mathematical community cannot allow themselves to accept NATO money, and in this case they had been informed that one of the most important contributors to the subject would not attend if NATO was involved. So the conference suffered badly from his absence and a number of important others. Not to speak of radical students and mathematicians from Communist and Third World countries. A conference supported by non-military funds-and, in fact, a smaller gathering could have been financed with money from the French

CNRS-could have achieved a higher level of scientific excellence and involved mathematicians in a truly international way, regardless of their political beliefs.

Yours faithfully, Stuart W. ElliotT

University of Cambridge,

Department of Pure Mathematics and Mathematical Statistics,

16 Mill Lane,

Cambridge CB2 $1 S B$

\section{Terrorism in Vietnam}

SIR,--In a recent letter (Nature, 238, 57 ; 1972) Dr Lester Goldstein wondered why in your editorial on the "Deadly Irony of Terrorism" (Nature, 237, 301; 1972) concerning the tragic and useless death of Professor Aharon Katchalsky Katzir, no mention was made of the kind of terrorism going on in Vietnam. The editor states diplomatically that Vietnam is not part of Nature's parish. Does this mean that Nature is not concerned with the scientific developments and use of the most sophisticated weapons ever developed, the use of which implicates the responsibility of all scientists? If terrorism has become a routine in Vietnam, it is more than anywhere else because of the silence of responsible people, journals and governments, which is in fact a sign of complicity and acceptance. It is high time that Nature faced its responsibilities in this issue.

Yours faithfully,

M. ERRERA

R. THOMAS

Université Libre de Bruxelles,

Faculte des Sciences,

Rue des Chevaux 67,

1640 Rhode-St-Genèse

\section{Bukovsky}

SIR,- -I don't know how wise it is for Nature to be involved in political issues, but I was pleased to see your note on Medvedev's treatment in Kiev. If a man is famous, or such things happen at an international congress, we hear about them from his colleagues. The only other way to get information is often to receive it from the Soviet Union by people like Vladimir Bukovsky, who was brave enough to send it.

Bukovsky, however, has received a twelve year sentence for sending details which he thinks show that other persons have been unreasonably detained in mental hospitals for political dissent. The documents he openly despatched to the West contained six case histories; they have something in common with the story detailed in Medvedev's book A Question of Madness.

Despite the guarantees of the Soviet Constitution it is well known that protest is only possible in the West. Hence with other psychiatrists a statement was produced stating that the documents raised grave doubts and at least what Bukovsky sent should be widely discussed. Since then five of the six persons mentioned have been released, but not General Grizorenko, who is apparently physically unwell and ageing.

It is natural, therefore, that many of us now feel it important to keep attention on the plight of Bukovsky. This unusual man seems quite unconcerned for his own welfare. $\mathrm{He}$ continually protests; he openly gave an interview for Western television but he does not seem to have committed any crime. He has, however, suffered repeated exile, compulsory hospitalization and imprisonment for his forthrightness.

Yours faithfully,

F. A. JENNER

University Department of Psychiatry, Whiteley Wood Clinic,

Sheffield 10

\section{Ehrlich-Maddox}

SIR,-I should like to correct an absurdity which somehow crept into my letter to Nature $(\mathbf{2 3 8}, 115 ; 1972)$ on the Ehrlich--Maddox controversy. I appear to have said: ". . . much of the resistance to expansion comes from the vested interest of industrialists ...". What I intended to say was, of course, ". . . much of the resistance to constraints on expansion ...".

Yours faithfully,

ANTHONY WREN

26 Rosemont Court,

Rosemont Road, Acton,

London W3 9LS 